\title{
Coconut Oil Based Microemulsion Formulations for Hair Care Product Application
}

(Mikroemulsi Berasaskan Minyak Kelapa untuk Kegunaan Produk Penjagaan Rambut)

\author{
SAFIAH MOHAMAD JA’AFAR, ROZIDA MOHD. KHALID, RIZAFIZAH OTHAMAN,
} WAN NUR AINI WAN MOKHTAR \& SURIA RAMLI*

\begin{abstract}
Coconut oil in microemulsion is a better option than conventional practice since it can incorporate bioactive ingredients with a stable control release property, especially for hair care products. This work aims to develop microemulsion systems based on coconut oil with the addition of Tween 20, Tween 40, and Tween 80 as non-ionic surfactants $(S)$, and propylene glycol as a co-surfactant $(\mathrm{CoS})$. The determination of microemulsion regions in the ternary phase diagram was carried out by water titration method and the properties of the microemulsion were analysed. Based on the results, the microemulsion system of coconut oil with Tween 80 produced the largest microemulsion region compared to Tween 40 and Tween 20. Microemulsion systems of coconut oil/Tween 80 with the addition of propylene glycol with the ratio of $S / C o S$ at $K m=3: 1,2: 1$, and 1:1 resulted in a decrement of microemulsion regions compared to using merely Tween 80. The microemulsion system of coconut oil/Tween 80/water at the ratio of oil: surfactant $=1: 9$ was chosen for further characterisations. Viscosity and electrical conductivity studies showed that the microemulsion system was water-in-oil (w/o) type as there was no phase transition to bicontinuous (BC) or oil-in-water (o/w) type due to low percentage of water content. Stability studies showed that the microemulsion system remained clear and stable at 25 and $40^{\circ} \mathrm{C}$ upon onemonth storage except at $4^{\circ} \mathrm{C}$ where the system became cloudy and turbid. For particle size analysis, the microemulsion system possessed particle size less than $100 \mathrm{~nm}$.
\end{abstract}

Keywords: Coconut oil; microemulsion; ternary phase diagram; Tween surfactants

\section{ABSTRAK}

Minyak kelapa sebagai mikroemulsi adalah lebih baik daripada penggunaannya secara konvensional kerana ia dapat menambah bahan bioaktif untuk dilepaskan dalam keadaan terkawal dan stabil untuk kegunaan produk penjagaan rambut. Tujuan kajian ini dijalankan adalah untuk menghasilkan sistem mikroemulsi berasaskan minyak kelapa dengan surfaktan jenis Tween 20, Tween 40 dan Tween 80 sebagai surfaktan bukan ionik (S) dan penambahan propilena glikol sebagai ko-surfaktan (CoS). Rantau pembentukan mikroemulsi pada rajah fasa ternari ditentukan dengan menggunakan kaedah penitratan air dan sifat mikroemulsi tersebut dianalisis. Keputusan menunjukkan sistem mikroemulsi minyak kelapa dengan Tween 80 menghasilkan rantau mikroemulsi paling luas berbanding Tween 40 dan Tween 20. Sistem mikroemulsi minyak kelapa/Tween 80 dengan penambahan propilena glikol dengan nisbah S/KoS pada Km=3:1, 2:1 dan 1:1 menunjukkan pengurangan rantau mikroemulsi berbanding menggunakan Tween 80 secara tunggal. Sistem mikroemulsi minyak kelapa/Tween 80/air pada nisbah minyak:surfaktan=1:9 dipilih bagi pencirian selanjutnya. Ujian konduktiviti elektrik dan kelikatan menunjukkan jenis sistem mikroemulsi air-dalam-minyak (w/o) dan tiada fasa transisi kepada sistem dwiselanjar (BC) disebabkan kandungan peratusan air yang rendah. Ujian kestabilan menunjukkan sistem mikroemulsi kekal jernih dan stabil pada suhu penyimpanan $25^{\circ} \mathrm{C}$ dan $40^{\circ} \mathrm{C}$ selama sebulan kecuali pada suhu $4^{\circ} \mathrm{C}$ kerana sistem menjadi kabur dan keruh. Bagi analisis saiz zarah, sistem mikroemulsi mempunyai saiz zarah kurang daripada $100 \mathrm{~nm}$.

Kata kunci: Mikroemulsi; minyak kelapa; rajah fasa ternary; surfaktan Tween

\section{INTRODUCTION}

Microemulsion is of great interest in food, pharmaceutical, and cosmetic areas due to the possibility of enhancing the solubility and improving the bioavailability of hydrophobic bioactive compounds, flavours, and other nutrients. Furthermore, microemulsion is able to provide a well-controlled way to incorporate active ingredients and may protect the solubilised components from undesired degradation (Ramli et al. 2015; Spernath \& Aserin
2006; Zainuddin et al. 2017). Microemulsion has many advantages over conventional emulsions, including low viscosity, small droplet size, and can form spontaneously without mechanical energy input (Lawrence \& Rees 2012). In addition, microemulsion is a thermodynamically stable, transparent, and isotropic dispersion with particle sizes ranging from 1-100 $\mathrm{nm}$ (Joshi \& Bhagwat 2013). It is composed of water, oil, and surfactants, typically in the combination of a co-surfactant (Mohd Nadzir et al. 2017; 
Talegaonkar et al. 2008). A surfactant forms a film at the internal surface whereas a co-surfactant is usually required to lower the interfacial tension of this interface because a low interfacial tension is essential for the formation of microemulsion ( $\mathrm{Lv}$ et al. 2006). Microemulsion may form a number of different structures, including oil-in-water (o/w) or water-in-oil (w/o) droplets (Akter et al. 2014), and bicontinuous $(\mathrm{BC})$ structures, over a wide range of compositions depending on the properties of oil and surfactants (Ke et al. 2005).

Most hair care applications use microemulsion-based products due to the advantages discussed earlier, and some previous findings already discussed the use of virgin coconut oil (VCO) in microemulsion studies (Marina et al. 2009; Rukmini et al. 2012; Sanjeewani et al. 2013). Thus, this study used refined coconut oil instead of VCO because coconut oil is traditionally used for improving hair texture and health, as well as thickening hair (Gavazzoni Dias 2015), in addition to a cheaper source. Generally, coconut oil is produced through dry method from copra (dried coconut meat), whereas VCO is obtained from fresh, mature kernel of the coconut by mechanical or natural means, with or without the use of heat and without undergoing chemical refining (Villarino et al. 2007). However, the main disadvantage of direct use of VCO for hair care is the rapid hydrolytic rancidity of the fatty acids in coconut oil, which makes hair smells unpleasant (Talbot 2016). Hence, using coconut oil is preferable over VCO as a base for hair care products (Spernath \& Aserin 2006).

Coconut oil is one of the most important oil crops and in terms of total planted area in Malaysia, coconut is the fourth important industrial crops after oil palm, rubber, and paddy (Norhayati et al. 2016). Coconut oil, being lauric acid-based oils, has many uses in the pharmaceutical and cosmetic industries (Mahdi et al. 2011). For non-edible purposes, coconut oil is an excellent material due to its desirable properties such as good biodegradability, nonoily character, and mildness to skin (Man \& Manaf 2006). Microemulsification of oils from plants such as coconut oil is a challenging task due to the fatty acid contained in triglycerides that may differ in chain length and degree of saturation (Joshi \& Bhagwat 2013). Factors such as ratio of surfactant to co-surfactant, chain length compatibility of oil and surfactant, and type of hydrocarbon in oil have been reported to affect the formation of microemulsion (Basheer et al. 2013; Syed \& Peh 2014). Nevertheless, very few studies of microemulsion-based coconut oil using non-ionic surfactants have been reported in the literature. Non-ionic surfactants usually used in pharmaceutical and cosmetic applications are sugar esters, polyoxyethylene sorbitan esters (Tweens), and polyoxyethylene ethers due to their relatively low toxicity and irritational potential. Non-ionic surfactants are recognised as being safe and biocompatible, as well as less affected by $\mathrm{pH}$ changes due to uncharged properties (Cho et al. 2008). Shortto-medium chain alcohols (C3-C8) are commonly used as co-surfactants to lower the interfacial tension at the interface (Azeem et al. 2008). Due to irritancy from usage of alcohol, propylene glycol is chosen as a cosurfactant as it is relatively tolerable to skin (Syed \& Peh 2014). Therefore, the main objective of this work was to develop microemulsion systems based on coconut oil with non-ionic surfactants and the addition of propylene glycol as a co-surfactant. The physicochemical properties of the chosen microemulsion system are studied in terms of viscosity, electrical conductivity, stability, and particle size. The potential formulation can then be used as a base for hair care products such as hair serum or conditioner.

\section{MATERIALS AND METHODS}

Pure edible refined coconut oil used is a product of $\mathrm{M} / \mathrm{S}$ Marico Industries Ltd (India). Non-ionic surfactant, polyoxyethylene sorbitan monooleate (Tween 80), polyoxyethylene sorbitan monopalmitate (Tween 40), polyoxyethylene sorbitan monolaurate (Tween 20) and propylene glycol was purchased from Merck (M) Sdn. Bhd. The oil and materials were used as received without further purification. Deionized water was used throughout the experiments.

For the formation of microemulsions, the ternary phase diagram that consists of oil, water, surfactant and surfactant/co-surfactant mixtures were constructed using water titration method. The titration method was done at ambient temperature $\left(25^{\circ} \mathrm{C}\right)$. For the formation of microemulsions with surfactant/co-surfactant mixtures, the phase diagrams were prepared with fixed weight ratio of surfactant/co-surfactant $(\mathrm{S} / \mathrm{CoS})(\mathrm{Km})$ as 3:1, $2: 1$ and $1: 1$. For each phase diagram, the weight of oil to surfactant or surfactant/co-surfactant $(\mathrm{S} / \mathrm{CoS})$ ratio were varied as $1: 9,2: 8,3: 7,4: 6,5: 5,6: 4,7: 3,8: 2$ and 9:1 (w/w) (Ramli et al. 2017, 2015; Zainuddin et al. 2017). The mixtures of oil, surfactant and co-surfactant were heated at 45 to $50^{\circ} \mathrm{C}$ and then cooled down to $25^{\circ} \mathrm{C}$ before titrating with water dropwise at 5 to $95 \mathrm{wt}$ \% water intervals using magnetic stirring. The mixtures were left for $24 \mathrm{~h}$ at ambient temperature before addition of water at each interval to check for any phase separation. After being equilibrated, the mixtures were assessed visually for fluidity, optically isotropy and phase separation and classified being as microemulsions, crude emulsions or gels. No attempt was made to distinguish between waterin-oil, bicontinuous or oil-in-water type microemulsions. Cross-polarized light microscopy was used to distinguish isotropic microemulsions from anisotropic phases. The resultant phase behavior was mapped on the ternary phase diagrams. The selected microemulsions along the water dilution lines were characterized for viscosity, conductivity, stability and particle size.

The viscosity of the various microemulsions was measured using Anton Paar Rheometer CC27-cylinderical rheometer probe (Physica MCR 301, Austria). $15 \mathrm{~mL}$ of microemulsions were tested at $25 \pm 0.2^{\circ} \mathrm{C}$. All systems were tested in triplicates $(n=3)$. The conductivity measurement of selected microemulsions was determined by using conductivity meter (Consort, Belgium). The 
measurements were performed in triplicate at $25 \pm$ $0.2^{\circ} \mathrm{C}$. A solution of $0.01 \mathrm{M}$ sodium chloride $(\mathrm{NaCl})$ was used instead of deionized water for the preparation of microemulsion samples. Thus, a small amount of aqueous electrolyte was added for electrical conduction as non-ionic surfactant was used. It should be noted that the samples remained clear and there were no observable changes in the ternary phase diagram. An electrode was dipped in the microemulsion samples until equilibrium was reached and reading became stable. The electrode was calibrated using standard $\mathrm{KCl}$ solution. Stability studies of microemulsions were studied via clarity and phase separation observation at different storage conditions at 4,25 and $40^{\circ} \mathrm{C}$ for a month. For droplet size analysis, the selected microemulsion samples were determined by dynamic light scattering (DLS) (Zetasizer Nano-ZS 90, Malvern, UK) technique. Each measurement was repeated three times at $25^{\circ} \mathrm{C}$.

\section{RESULTS AND DISCUSSION}

\section{TERNARY PHASE DIAGRAM OF MICROEMULSION SYSTEMS}

Ternary phase diagrams were constructed based on water dilution lines that demonstrated an increase in water content with decreasing surfactant/co-surfactant contents. In this work, ternary phase behaviour studies were carried out on coconut oil and Tween surfactants (Tween 20, 40 , and 80), with the effect of propylene glycol as a cosurfactant on the selected system. Figure 1 shows the ternary phase diagrams of coconut oil and Tween-based microemulsion system.

Based on Figure 1, the system of Tween 80/Coconut oil/Water formed microemulsion regions from 5 to 25 wt. \% water at the ratio of oil to surfactant of 1:9 and $2: 8$. A highly viscous or gel system was formed from 30 to 55 wt. $\%$ water at the ratio of oil: surfactant $=1: 9$ as it remained unchanged in the meniscus after tilting to an angle $90^{\circ}$ (unlabelled in the phase diagram). Other ratios of oil to surfactant formed cloudy and turbid mixtures and followed by phase separation, indicating the formation of emulsion systems.

Tween surfactants used in this study are structurally similar in polyoxyethylene (hydrophilic group) but different in the tail part (hydrophobic group). The tail group of Tween 80 is composed of unsaturated oleic acid (monooleate), whereas Tween 40 and Tween 20 are composed of palmitic acid (monopalmitate) and lauric acid (monolaurate), respectively. From Figure 1, it can be seen that the microemulsion system of Tween 80 /Coconut oil/ Water produced the largest microemulsion region, which was $9.3 \%$ compared to Tween 40 and Tween 20 of 6.5 and $0 \%$ (data not shown), respectively. It is due to a large molecular packing ratio of Tween 80 that is classified as a strong solubiliser (Mahdi et al. 2011). However, by replacing Tween 80 with Tween 40 and Tween 20, which are more hydrophilic surfactants, the resulting systems were less efficient in stabilising the oil and water interface of Tween 40/Coconut oil/Water and Tween 20/coconut oil/ water. The system of Tween 40/Coconut oil/Water formed microemulsion regions at 5 to $30 \mathrm{wt} . \%$ water at the ratio of oil: surfactant $=1: 9$, whereas Tween 20/Coconut oil/ Water system showed no formation of microemulsion region in the ternary phase diagram. The system containing Tween 20 showed very poor stability and did not form microemulsion. This result might be due to the different properties of Tween 80, Tween, 40 and Tween 20 such as Hydrophile-Lipophile Balance (HLB) value (15.0, 15.6 , and 16.7, respectively). Due to the similarity of the hydrophobic tail of Tween 20 with the major composition of coconut oil, which is lauric acid, Tween 20 is unable to reduce the interfacial tension of water-oil system. This indicates a weak interaction between the oil and surfactant from the same fatty acid composition, even though Tween 20 is more hydrophilic compared to Tween 80 and Tween 40 as supported by Mahdi et al. (2011).

The microemulsion system of Tween 80/Coconut oil/Water was chosen for further study on the effect of propylene glycol as a co-surfactant. Referring to Figure 2 , the region of microemulsion for Tween 80/Propylene glycol/Coconut oil/Water $(\mathrm{Km}=3: 1)$ formed was $3.9 \%$, which was slightly smaller than the system without propylene glycol (9.3\%) (Figure 1(a)). The microemulsion region formed up to $20 \mathrm{wt}$. \% water at the ratio of oil:S/ $\mathrm{CoS}=1: 9$ as shown in Figure 2(a), whereas for $\mathrm{Km}=$ $2: 1$, the region of microemulsion produced was only $1 \%$. Meanwhile, for the ratio of $\mathrm{Km}=1: 1$, no microemulsion region was obtained in the phase diagram as cloudy and turbid mixtures appeared, followed by phase separation.

It is presumed that a considerable part of propylene glycol is incorporated into the surfactant layer and will increase the interfacial fluidity of the interface to extend the formation of microemulsion region (Syed \& Peh 2014). However, it was found that the addition of propylene glycol into the Tween 80/Coconut oil/Water microemulsion system reduced the formation region of microemulsion and reduced the isotropic region for both $\mathrm{Km}=3: 1$ and $2: 1$ of the single-phase microemulsion, in which a low amount of oil and water can be solubilised. The co-surfactant might disturb the stability of a microemulsion system, which resulted in destruction of the microemulsion upon dilution of water (Warisnoicharoen et al.2000). Therefore, the area of the microemulsion region consists of propylene glycol acting as a co-surfactant was considerably smaller, which were $3.9 \%$ and $1.0 \%$ for $\mathrm{Km}=$ $3: 1$ and $2: 1$, respectively, compared to the system without propylene glycol $(9.3 \%)$. Furthermore, this might be due to the coconut oil used as the oil phase is a triglyceride. Triglycerides are not capable of forming a separate domain in an amphiphile-water system, resulting in a much smaller formation of microemulsion area rather than oil (Paul \& Moulik 2001). Therefore, the microemulsion system with Coconut oil/Tween 80/Water at the ratio of oil: surfactant $=1: 9$ was chosen for further formulation's characterization as denoted by the dotted arrow of water dilution line in Figure 1(a). 


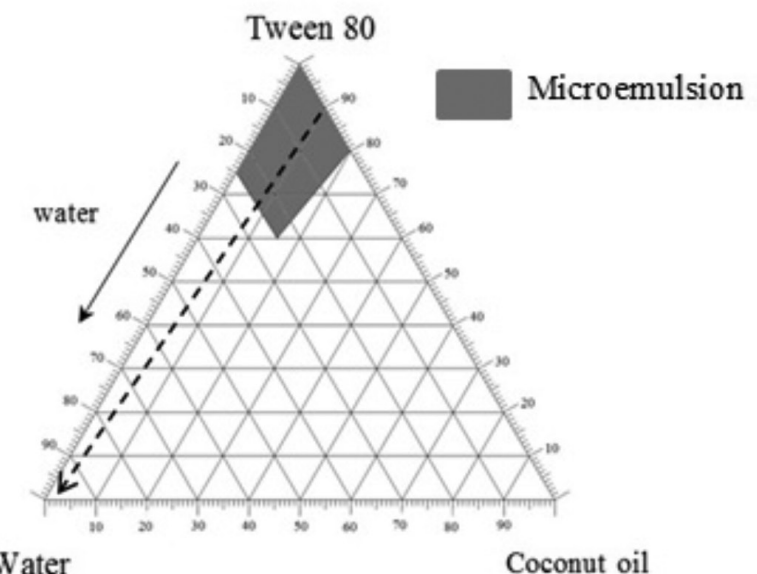

(a)

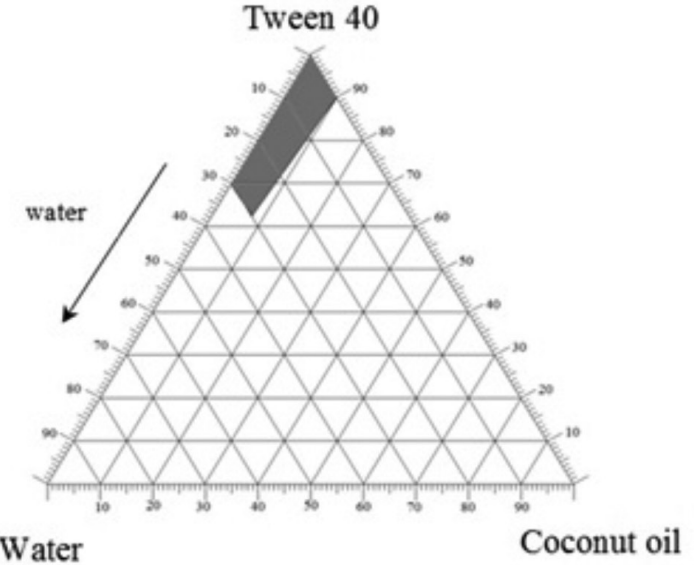

(b)

FIGURE 1. (a) Ternary phase diagram of system Tween 80/ Coconut oil/Water (b) Ternary phase diagram of system Tween 40/Coconut oil/Water

\section{ELECTRICAL CONDUCTIVITY}

Electrical conductivity measurement provides structural information used to determine whether microemulsion is oil-continuous (w/o), bicontinuous $(\mathrm{BC})$, or watercontinuous $(\mathrm{o} / \mathrm{w})$. The transitions are detected by conductivity slope changes, indicating the existence of different microemulsion structures (Kogan et al. 2007). Figure 3 shows that electrical conductivity increases as the water concentration increases. The system has low conductivity at $5 \mathrm{wt}$ \% water, but increases slowly with increasing water content up to $15 \mathrm{wt}$. \% water. It is assumed that the system represents w/o microemulsion system because water droplets are discrete in an oil continuum and therefore possesses weak interaction. Extremely low conductivity is the characteristic of a water-in-oil microemulsion (Constantinides \& Scalart 1997). When water exists as isolated droplets in the continuous phase (w/o), conductivity is expected to be poor because charges are carried in the aqueous phase and not in the oil phase. Normally, the conductivity of a system increases continuously with an increase in water content, followed by a sigmoid curve and rising sharply at a critical water

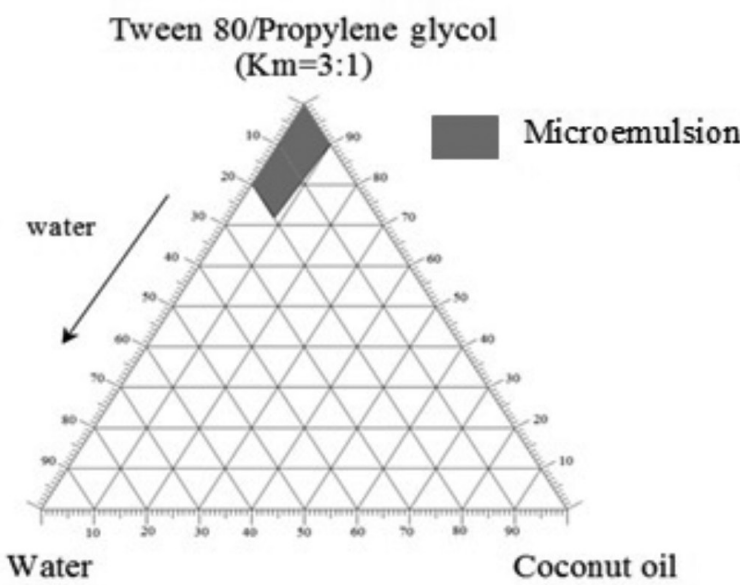

(a)

Tween 80/Propylene glycol $(\mathrm{Km}=2: 1)$

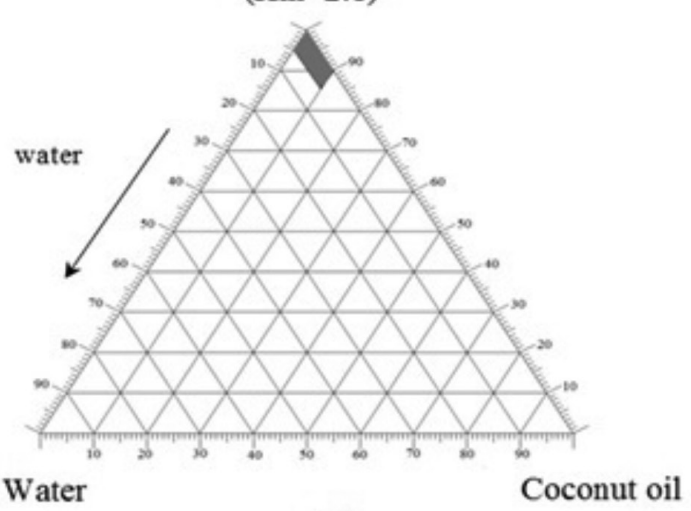

(b)

FIGURE 2. Ternary phase diagram of system Tween $80 /$ Propylene glycol/Coconut oil/Water for (a) $\mathrm{Km}=3: 1$ and (b) $\mathrm{Km}=2: 1$

concentration known as percolation threshold (Ramli 2013). Above 15 wt. \% water, a drastic increase in conductivity is observed. Typically, increasing conductivity is due to the efficient transfer of charge between droplets by either charge hopping or transient merging of connected droplets with the interaction between the water cores. The increasing interaction between the water domains enable the formation of continuous bridges and water entrapped within the oil phase becomes a continuous phase with an interconnected conductive channel, which is a bicontinuous phase. Unfortunately, there was no phase transition to oilin-water phase, as there were no significant changes in the slope as reported by Mehta et al. (1994) and Podlogar et al. (2004).

\section{VISCOSITY}

Viscosity measurement is required for microemulsion in order to characterize the system physically. Viscosity depends largely on the microemulsion structure; therefore, any changes in microstructures related to microstructural changes in microemulsion, such as from isolated droplets to an interconnected bicontinuous structure or vice versa, 


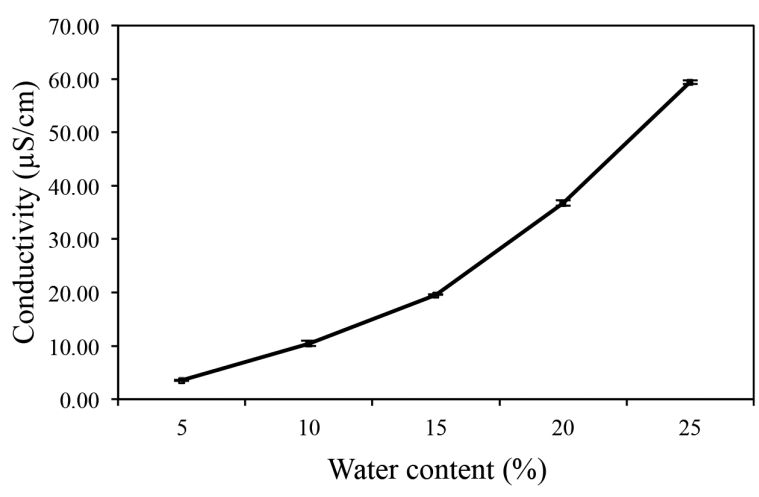

FIGURE 3. Electrical conductivity measurement of microemulsion system

will lead to changes in viscosity (Garti et al. 2006). Figure 4 shows low viscosity at 5 wt. \% water content, followed by an increment in viscosity when water content increased up to $15 \mathrm{wt}$. \% water. In this oil-rich region, the very low viscosity indicates weak interactions of water droplets due to the low water fraction. An increase in viscosity with increasing volume fraction of dispersed phase in the microemulsion is believed to reflect a w/o microemulsion type and the opposite behaviour suggests an $\mathrm{o} / \mathrm{w}$ microemulsion. With further addition of water, a sharp increase was observed for water content from 15 to $25 \mathrm{wt}$. $\%$ water. The increase of viscosity indicates a change in the internal structure due to swelling of water droplets, as well as the changing shape of droplets due to increased attractive interdroplet interaction and aggregation. Moreover, structural effects arise from changes in interfacial packing that induce cluster formation as water begins to migrate out of the inner phase resulting in interconnected water and oil channels and the progressive formation of a bicontinuous phase. However, in this system, no changes in microstructure occurred to $\mathrm{o} / \mathrm{w}$ as the microemulsion formed until only $25 \mathrm{wt}$. \% water content. There was no further dilution of water beyond 25 wt. $\%$ water as the microemulsion region formed was up to $25 \% \mathrm{wt}$. water.

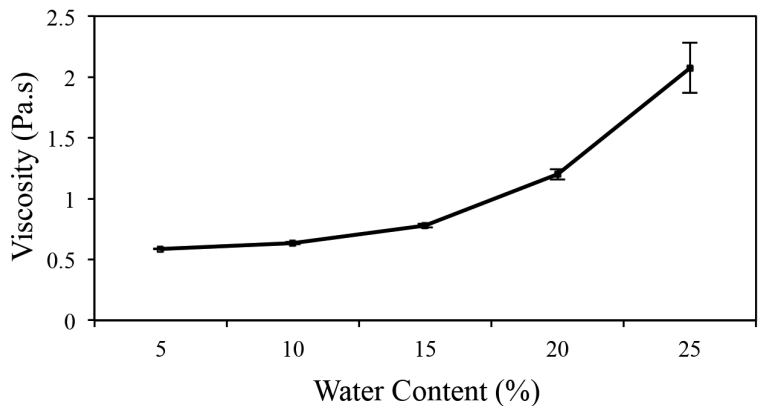

FIGURE 4. Viscosity measurement of microemulsion system

\section{STABILITY STUDIES}

Three different temperatures $\left(4,25\right.$, and $\left.40^{\circ} \mathrm{C}\right)$ were imposed on microemulsion systems for four weeks to examine their stability. Based on the observation as shown in Figure 5, microemulsions of 5-25 wt. \% water remained clear and stable at 25 and $40^{\circ} \mathrm{C}$ without any phase separations upon one-month storage. Unfortunately, the microemulsions were unstable and became turbid when stored at $4^{\circ} \mathrm{C}$. This is because coconut oil has low range of melting point (Man \& Manaf 2006) and causing the microemulsion system to solidify, and become cloudy and turbid at low temperature (Tubtimsri et al. 2014).
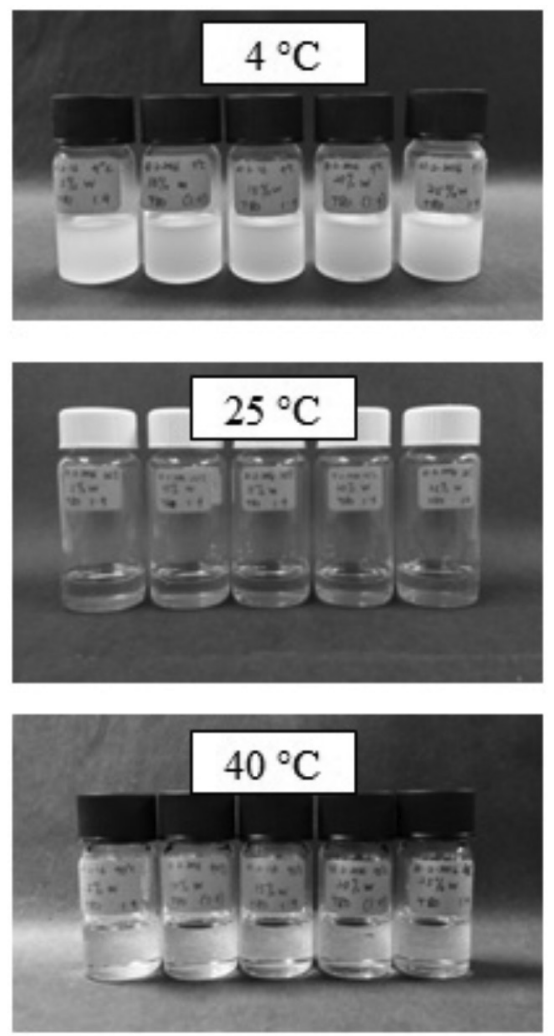

FIGURE 5. Stability studies conducted upon one month storage at $4^{\circ} \mathrm{C}, 25^{\circ} \mathrm{C}$ and $40^{\circ} \mathrm{C}$

\section{PARTICLE SIZE}

Average particle diameter sizes are important characterization to determine the particle size distribution in microemulsion (Ramli et al. 2015), as well as predicting the physical stability of microemulsion (Ramli et al.2009). Small droplet size provides high stability of a system against sedimentation, flocculation, and coalescence (Cho et al. 2008). Table 1 summarizes that the microemulsion system has particle diameter size less than $70 \mathrm{~nm}$ and within the range of microemulsion particle size (1-100 nm).

\section{CONCLUSION}

Ternary phase diagrams of the microemulsion systems of Tweens/Coconut oil/Water and with the addition of propylene glycol as a co-surfactant have been successfully constructed. The microemulsion system of Tween 80/ Coconut oil/Water produced a larger microemulsion 
TABLE 1. Particle size of microemulsion system

\begin{tabular}{cc}
\hline $\begin{array}{c}\text { Water content } \\
(\%)\end{array}$ & $\begin{array}{c}\text { Average particle size, } \\
\mathrm{d}(\mathrm{nm})\end{array}$ \\
\hline 5 & 68.61 \\
10 & 48.44 \\
15 & 10.78 \\
20 & 7.33 \\
25 & 3.48 \\
\hline
\end{tabular}

area compared to the system with propylene glycol, which reduced the formation area of microemulsion. The system showed stability at 25 and $40^{\circ} \mathrm{C}$ upon one-month storage. The viscosity and electrical conductivity studies showed w/o and $\mathrm{BC}$ microemulsion with particle diameter size below $100 \mathrm{~nm}$. Therefore, these results showed that coconut oil in a microemulsion system is stable and suitable for further applications in hair care products.

\section{ACKNOWLEDGEMENTS}

The authors would like to thank Universiti Kebangsaan Malaysia for supporting this work through the Research University Grant (GUP-2015-017) and Researcher Incentive Grant (GGP-2017-087).

\section{REFERENCES}

Akter, N., Radiman, S., Mohamed, F. \& Ramly, N.B. 2014. Investigation of the gelation mechanism between amino acid surfactant based microemulsion and kappa-carrageenan gel network. Sains Malaysiana 43(2): 203-209.

Azeem, A., Rizwan, M., Ahmad, F.J., Khan, Z.I., Khar, R.K., Aqil, M. \& Talegaonkar, S. 2008. Emerging role of microemulsions in cosmetics. Recent Patents on Drug Delivery \& Formulation 2(3): 275-289.

Basheer, H.S., Noordin, M.I. \& Ghareeb, M.M. 2013. Characterization of microemulsions prepared using isopropyl palmitate with various surfactants and co-surfactants. Tropical Journal of Pharmaceutical Research 12(3): 305-310.

Cho, Y.H., Kim, S., Bae, E.K., Mok, C.K. \& Park, J. 2008. Formulation of a cosurfactant-free $\mathrm{O} / \mathrm{W}$ microemulsion using nonionic surfactant mixtures. Journal of Food Science 73(3): E115-E121.

Constantinides, P.P. \& Scalart, J.P. 1997. Formulation and physical characterization of water-in- oil microemulsions containing long- versus medium-chain glycerides. International Journal of Pharmaceutics 158(1): 57-68.

Garti,N.,Avrahami,M.\& Aserin,A. 2006. Improved solubilization of celecoxib in U-type nonionic microemulsions and their structural transitions with progressive aqueous dilution. Journal of Colloid and Interface Science 299(1): 352-365.

Gavazzoni Dias, M.F.R. 2015. Hair cosmetics: An overview.Int . J. Trichology 7(1): 2-15.

Grimwood, B.E., Ashman, F., Dendy, D.A.V., Jarman, C.G., Little, E.C.S. \& Timmins, W.H. 1975. Coconut palm products - Their processing in developing countries. Rome: FAO. ISBN 978-92-5-100853-9. p. 193.

Joshi, S.S. \& Bhagwat, S.S. 2013. Physicochemical behaviour of ternary system based on coconut oil/ $\mathrm{C}_{2} \mathrm{E}_{8} / \mathrm{n}$-pentanol/water. Journal of Surface Science and Technology 29(1-2): 1-13.
Ke, W.T., Lin, S.Y., Ho, H.O. \& Sheu, M.T. 2005. Physical characterizations of microemulsion systems using tocopheryl polyethylene glycol 1000 succinate (TPGS) as a surfactant for the oral delivery of protein drugs. Journal of Controlled Release 102(2): 489-507.

Kogan, A., Aserin, A. \& Garti, N. 2007. Improved solubilization of carbamazepine and structural transitions in nonionic microemulsions upon aqueous phase dilution. Journal of Colloid and Interface Science 315(2): 637-647.

Lawrence, M.J. \& Rees, G.D. 2012. Microemulsion-based media as novel drug delivery systems. Advanced Drug Delivery Reviews 64(0): 175-193.

Lv, F.F., Li, N., Zheng, L.Q. \& Tung, C.H. 2006. Studies on the stability of the chloramphenicol in the microemulsion free of alcohols. European Journal of Pharmaceutics and Biopharmaceutics 62(3): 288-294.

Marina, A.M., Che Mana, Y.B. \& Amin, I. 2009. Virgin coconut oil: Emerging functional food oil. Trends in Food Science \& Technology 20: 481-487.

Mahdi,E.S., Sakeena, M.H.F.,Abdulkarim, M.F.,Abdullah, G.Z., Sattar, M.A. \& Noor, A.M. 2011. Effect of surfactant and surfactant blends on pseudoternary phase diagram behavior of newly synthesized palm kernel oil esters. Drug Design, Development and Therapy 5: 311-323.

Man,Y.B.C. \& Manaf, M.A. 2006. Medium-chain triacylglycerols. Dlm Nutraceutical and Specialty Lipids and Their CoProducts. Boca Raton: CRC Press. p. 27.

Mehta, S.K., Dewan, R.K. \& Bala, K. 1994. Percolation phenomenon and the study of conductivity, viscosity, and ultrasonic velocity in microemulsions. Physical Review E 50(6): 4759-4762.

Mohd Nadzir, M., Fen, T.W., Mohamed, A.R. \& Hisham, S.F. 2017. Size and stability of curcumin niosome from combinations of tween 80 and span 80. Sains Malaysiana 46(12): 2455-2460.

Norhayati, Y., Afzan, A., Jannah, S. \& Nurul, W. 2016. Antioxidative responses of Cocos nucifera against infestation by the Red Palm Weevil (RPW), Rhynchophorus ferrugineus, a new invasive coconut pest in Malaysia. Sains Malaysiana 45(7): 1035-1040.

Paul, B.K. \& Moulik, S.P. 2001. Uses and applications of microemulsions. Current Science 80(8): 990-1001.

Podlogar, F., Gašperlin, M., Tomšič, M., Jamnik, A. \& Rogač, M.B. 2004. Structural characterisation of water-Tween $40 ® /$ Imwitor 308®-isopropyl myristate microemulsions using different experimental methods. International Journal of Pharmaceutics 276(1-2): 115-128.

Ramli, S. 2013. Surfactant protein B-based microemulsion as transdermal drug carrier for anti-acne agent. PhD Thesis. The University of Queensland Australia (Unpublished).

Ramli, S., Norhman, N., Zainuddin, N., Mohd Ja'afar, S. \& Abdul Rahman, I. 2017. Nanoemulsion based palm olein as vitamin E carrier. Malaysian Journal of Analytical Sciences 21(6): 1399-1408.

Ramli, S., Mohd Ja'afar, S., Abdul Sisak, M.A., Zainuddin, N. \& Abdul Rahman, I. 2015. Formulation and physical characterization of microemulsion based carboxymethyl cellulose as vitamin C carrier. Malaysian Journal of Analytical Sciences 19(1): 275-283.

Ramli, S., Ross, B.P. \& Gentle, I.R. 2009. Formulation and physical characterization of microemulsions containing isotritenoin. International Conference on Biomedical and Pharmaceutical Engineering. pp. 1-7. 
Rukmini, A., Raharjo, S. \& Supriyadi, S. 2012. Formulation and stability of water-in-virgin coconut oil microemulsion using ternary food grade nonionic surfactants. International Food Research Journal 19(1): 259-264.

Sanjeewani, N.A. \& Sakeena, M.H.F. 2013. Formulation and characterization of virgin coconut oil (VCO) based emulsion. International Journal of Scientific and Research Publications 3(12): 1-6.

Spernath, A. \& Aserin, A. 2006. Microemulsions as carriers for drugs and nutraceuticals. Advances in Colloid and Interface Science 128-130: 47-64.

Syed, H.K. \& Peh, K.K. 2014. Identification of phases of various oil, surfactant/co-surfactants and water system by ternary phase diagram. Acta Poloniae Pharmaceutica-Drug Research 71(2): 301-309.

Talbot, G. 2016. The stability and shelf life of fats and oils. In The Stability and Shelf Life of Food. 2nd ed., edited by Persis Subramaniam \& P. Wareing. Cambridge: Woodhead Publishing pp. 461-503

Talegaonkar, S., Azeem, A., Ahmad, F.J., Khar, R.K., Pathan, S.A. \& Khan, Z.I. 2008. Microemulsions: A novel approach to enhanced drug delivery. Recent Patents on Drug Delivery \& Formulation 2(3): 238-257.

Tubtimsri, S., Limmatvapirat, C., Sriamornsak, P. \& Limmatvapirat, S. 2014. Determination of required hydrophile-lipophile balance value of modified coconut oil. Advanced Materials Research 1060: 172-175.
Villarino, B.J., Dy, L.M. \& Lizada, C.C. 2007. Descriptive sensory evaluation of virgin coconut oil and refined, bleached and deodorized coconut oil. LWT 40: 193-199.

Warisnoicharoen, W., Lansley, A.B. \& Lawrence, M.J. 2000. Nonionic oil-in-water microemulsions: The effect of oil type on phase behaviour. International Journal of Pharmaceutics 198(1): 7-27.

Zainuddin, N., Ahmad, I., Abdul Rahman, I. \& Ramli, S. 2017. Kesan penambahan limonene terhadap mikroemulsi asid oleic/Cremophor Rh 40/Transcutol/Air. Sains Malaysiana 46(10): 1797-1805.

Centre for Advanced Materials and Renewable Resources Faculty of Science and Technology

Universiti Kebangsaan Malaysia 46300 UKM Bangi, Selangor Darul Ehsan Malaysia

*Corresponding author; email: su_ramli@ukm.edu.my

Received: 15 September 2018

Accepted: 28 November 2018 